OAK RIDGE NATIONAL

\section{LABORATORY}

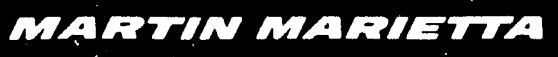

\section{Low-Level Liquid Waste Decontamination by Ion Exchange}

\author{
D. O. Campbell \\ D. D. Lee \\ T. A. Dillow
}


Chemical Technology Division

\title{
Low-Level Liquid Waste Decontamination by Ion Exchange
}

\author{
D. O. Campbell \\ D. D. Lee \\ T. A. Dillow \\ Date of Issue - December 1991 \\ Prepared by the \\ OAK RIDGE NATIONAL LABORATORY \\ Oak Ridge, Tennessee 37831 \\ managed by \\ MARTIN MARIETTA ENERGY SYSTEMS, INC. \\ for the \\ U.S. DEPARTMENT OF ENERGY \\ under contract DE-AC05-84OR21400
}


CONTENTS

LIST OF TABLES $\ldots \ldots \ldots \ldots \ldots \ldots \ldots \ldots \ldots \ldots \ldots \ldots \ldots \ldots \ldots \ldots \ldots$

LIST OF FIGURES $\ldots \ldots \ldots \ldots \ldots \ldots \ldots \ldots \ldots \ldots \ldots \ldots \ldots$

ACRONYMS AND INITIALISMS $\ldots \ldots \ldots \ldots \ldots \ldots \ldots \ldots \ldots \ldots \ldots \ldots$ vii

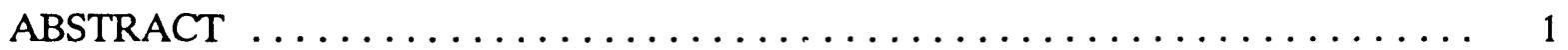

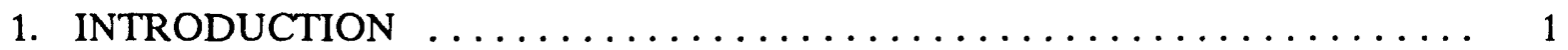

2. LIQUID WASTE TREATMENT PROCESSES $\ldots \ldots \ldots \ldots \ldots \ldots \ldots \ldots$

3. CESIUM REMOVAL WITH HEXACYANOFERRATE(II) COMPOUNDS . . . 4

4. PROCESS APPLICATION $\ldots \ldots \ldots \ldots \ldots \ldots \ldots \ldots \ldots \ldots \ldots \ldots$

5. CESIUM AND STRONTIUM REMOVAL WITH ORGANIC ION-EXCHANGE

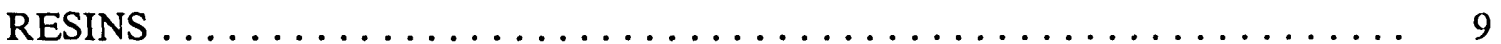

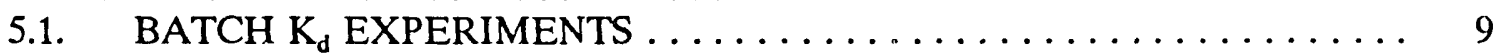

5.2. ION-EXCHANGE COLUMN TESTS $\ldots \ldots \ldots \ldots \ldots \ldots \ldots \ldots \ldots \ldots$

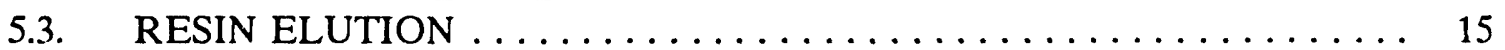

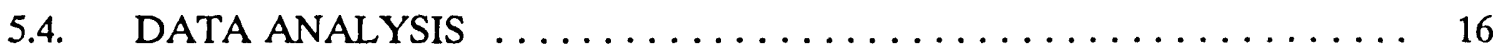

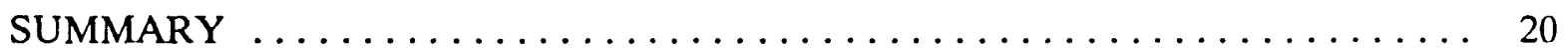

REFERENCES .............................. 23 


\section{LIST OF TABLES}

$\underline{\text { Pagc }}$

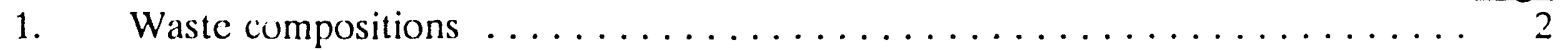

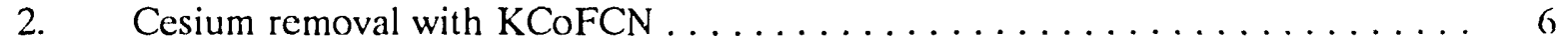

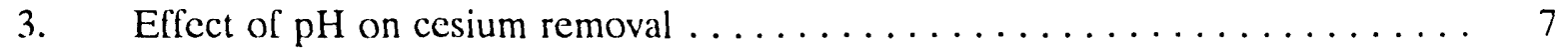

4. Decontamination of LLLW supernate solution $\ldots \ldots \ldots \ldots \ldots \ldots \ldots$

5. ${ }^{137} \mathrm{Cs}$ removal from process waste $\ldots \ldots \ldots \ldots \ldots \ldots \ldots \ldots \ldots \ldots \ldots \ldots \ldots$

6. Comparison of batch $\mathrm{K}_{\mathrm{d}}$ data for $\mathrm{SRS}$ resin for various potassium, sodium,

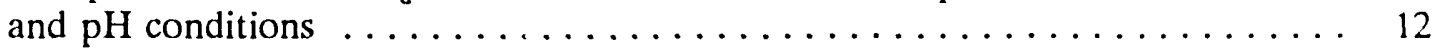

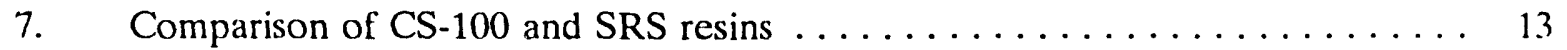

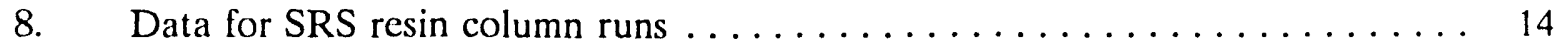

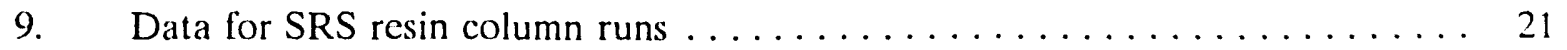

\section{LIST OF FIGURES}

1. Two-stage IX-UF process for LLLW $\ldots \ldots \ldots \ldots \ldots \ldots \ldots \ldots \ldots \ldots$

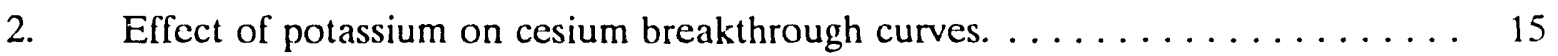

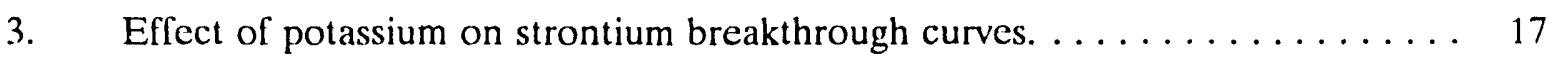

4. Cesium Kds for column iests by graphical and breakthrough function methods. . 18

5. Elution of activity from SRS resin. . . . . . . . . . . . . . 20

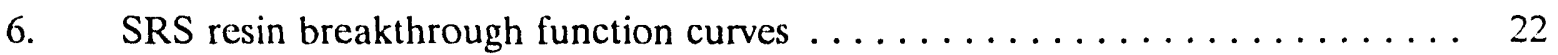




\section{ACRONYMS AND INITIALISMS}

\begin{tabular}{|c|c|}
\hline AMFCN & $\begin{array}{l}\text { Nonstoichiometric compound of formula } \mathrm{A}_{\mathrm{n}} \mathrm{M}_{(2-\mathrm{n} / 2)} \mathrm{Fe}(\mathrm{CN})_{6} \text { where } \mathrm{A} \text { is an } \\
\text { Alkali metal; } \mathrm{M} \text { is a metal such as } \mathrm{Ni}, \mathrm{Co}, \mathrm{Cu} \text {, or } \mathrm{Zn} \text {; and } \mathrm{FC} \text { is } \\
\text { ferrocyanide (i.e., NaNiFC for sodium nickel ferrocyanide) }\end{array}$ \\
\hline $\mathrm{CV}$ & Volume of resin in IX column \\
\hline $\mathrm{DF}$ & Decontamination factor $\left(\mathrm{C}_{0} / \mathrm{C}\right)$ \\
\hline FC & Transition metal hexacyanoferrate(II) compounds (ferrocyanide) \\
\hline HTU & Height of a transfer unit \\
\hline IX & Ion-exchange processes \\
\hline$K_{r} a$ & Mass transfer coefficient \\
\hline $\mathrm{K}_{\mathrm{d}}$ & Distribution coefficient \\
\hline $\mathrm{K}_{\mathrm{d}}^{\prime}$ & Volume-based distribution coefficient \\
\hline LLLW & Low-level (radioactive) liquid waste \\
\hline MVST & Melton Valley Storage Tanks \\
\hline $\mathrm{NaT}$ & Sodium titanate \\
\hline ORNL & Oak Ridge National Laboratory \\
\hline PW & Process waste \\
\hline SRS & Savannah River Site, DOE \\
\hline TRU & Transuranic \\
\hline
\end{tabular}


LOW-LEVEL LIQUID WASTE DECONTAMINATION BY ION EXCHANGE

\author{
D. O. Campbell \\ D. D. Lee \\ T. A. Dillow
}

\begin{abstract}
Improved processes are being developed to treat contaminated liquid wastes that have been and continue to be generated at Oak Ridge National Laboratory. Both inorganic and organic ion-exchange methods have given promising results. Nickel and cobalt hexacyanoferrate(II) compounds are extremely selective for cesium removal, with distribution coefficients in excess of $10^{6}$ and remarkable insensitivity to competition from sodium and potassium. They tend to lose effectiveness at $\mathrm{pH}>\sim 11$, but some formulations are useful for limited periods of time up to $\mathrm{pH} \sim 13$. Sodium titanate is selective for strontium removal at high $\mathrm{pH}$. The separations are so efficient that simple batch processes can yield large decontamination factors while generating small volumes of solid waste. A resorcinol-based resin developed at the Savannah River Site gave superior cesium removal, compared with other organic ion exchangers; the distribution coefficient was limited primarily by competition from potassium and was nearly independent of sodium. The optimum $\mathrm{pH}$ was $\sim 12.5$. It was much less effective for strontium removal, which was limited by competition from sodium.
\end{abstract}

\title{
1. INTRODUCTION
}

A variety of contaminated liquid wastes are produced at Oak Ridge National Laboratory (ORNL), and nearly all of them are collected in one of two systems-the process waste (PW) or the low-level liquid waste (LLLW). Representative liquid waste compositions are shown in Table 1. The PW includes liquids with very low concentrations of radioactivity as well as water that is not normally contaminated but might be. It is generated at the rate of $\sim 500 \mathrm{~L} / \mathrm{min}$ and has a composition essentially that of ordinary tap water or groundwater in 
Table 1. Waste compositions

\begin{tabular}{|c|c|c|c|}
\hline Component & PW & LLLW & Simulant \\
\hline $\mathrm{pH}$ & $\begin{array}{c}7.7 \\
(\mathrm{mg} / \mathrm{L})\end{array}$ & $\begin{array}{c}8-13 \\
(\mathrm{mg} / \mathrm{L})\end{array}$ & $\begin{array}{r}13.2 \\
(\mathrm{mg} / \mathrm{L}) \\
\end{array}$ \\
\hline Sodium & 20. & 110,000 & 104,000 . \\
\hline Potassium & 2. & 10,000 & 9,800 . \\
\hline Cesium & - & 0.34 & \\
\hline Calcium & 40. & 4.0 & 4. \\
\hline Magnesium & 10. & 0.02 & \\
\hline Strontium & 0.2 & 1.0 & \\
\hline Barium & - & 1.0 & \\
\hline Aluminum & 0.1 & 25.0 & 14. \\
\hline Chromium & $<0.02$ & 2.5 & \\
\hline Lead & - & 10. & \\
\hline Zinc & - & 50. & 65. \\
\hline Nitrate & 4. & 280,000 & 258,000 \\
\hline Carbonate & 60. & $8,000$. & 8,400 \\
\hline Sulfate & 18. & - & \\
\hline \multirow[t]{2}{*}{ Chloride } & 6. & 3,500 . & 3,550 \\
\hline & $(\mathrm{Bq} / \mathrm{L})$ & $(\mathrm{Bq} / \mathrm{L})$ & \\
\hline Gross alpha & 5. & $2 \times 10^{3}$ & \\
\hline Gross beta & 6000. & $2 \times 10^{8}$ & \\
\hline${ }^{60} \mathrm{Co}$ & 25. & $5 \times 10^{5}$ & \\
\hline${ }^{90} \mathrm{Sr}$ & 4000. & $4 \times 10^{6}$ & \\
\hline${ }^{137} \mathrm{Cs}$ & 400. & $2 \times 10^{6}$ & \\
\hline${ }^{134} \mathrm{Cs}$ & 10. & $6 \times 10^{6}$ & \\
\hline
\end{tabular}


the area; it contains small amounts of ${ }^{137} \mathrm{Cs},{ }^{134} \mathrm{Cs},{ }^{90} \mathrm{Sr}$, very small amounts of ${ }^{60} \mathrm{Co}$, and rarely other radioisotopes. The LLLW consists of waste concentrates from laboratorics, radiochemical processing operations, and waste treatment facilities. The volume is small, 10 to $20 \mathrm{~m}^{3} /$ year, but the liquid contains very high concentrations of dissolved solids.

The concept underlying the present work is that safety and economics would be improved if the wastes could be divided into three fractions:

1. The material, insoluble at high $\mathrm{pH}$, contains the transuranic (TRU) constituents (if present) and other heavy metals and must be treated accordingly.

2. A non-TRU concentrate containing the major beta-gamma radionuclides $\left({ }^{137} \mathrm{Cs}\right.$, ${ }^{134} \mathrm{Cs}$, and ${ }^{90} \mathrm{Sr}$ ) that, because of its small volume, can be managed with great care is recovered from the supernate.

3. The bulk of the liquid waste is decontaminated from radioactivity sufficiently that it can be managed as a less hazardous material than it now is, thereby opening up much-needed capacity in the existing storage tanks.

The hazardous radioactivity in the wastes is dominated by actinides, ${ }^{137} \mathrm{Cs}$, and ${ }^{90} \mathrm{Sr}$. Because the actinides are insoluble in alkaline LLLW, the supernate is generally a nonTRU waste. Therefore, supernate decontamination requires the removal of ${ }^{137} \mathrm{Cs}$ and ${ }^{90} \mathrm{Sr}$ from very large amounts of sodium and potassium and smaller amounts of other elements, including alkaline earths and transition metals. Experimental studies have been undertaken to develop improved processes to decontaminate the wastes by removing nearly all of the cesium and strontium. Methods under study include scavenging precipitation and column separations with selective ion-exchange materials; both organic and inorganic exchangers are included. Most of the experiments were conducted with a synthetic solution that approximates the liquid in some existing waste tanks (LLLW simulant); the composition is $3.9 \underline{\mathrm{M}} \mathrm{NaNO}_{3}, 0.25 \underline{\mathrm{M}} \mathrm{KNO}_{3}, 0.24 \underline{\mathrm{M} \mathrm{NaOH}}, 0.14 \underline{\mathrm{M} \mathrm{Na}} \mathrm{CO}_{3}, 0.10 \underline{\mathrm{M} \mathrm{NaCl}}, 0.001 \underline{\mathrm{M}}$ $\mathrm{Zn}\left(\mathrm{NO}_{3}\right)_{2}, 0.0005 \underline{\mathrm{M} \mathrm{Al}}\left(\mathrm{NO}_{3}\right)_{3}$, and $0.0001 \underline{\mathrm{M} C a C O}$. T? e $\mathrm{pH}$ was adjusted as necessary.

\section{LIQUID WASTE TREATMENT PROCESSES}

Until a few years ago, large volumes of LLLW were mixed with cement grout-forming chernicals and injected into a shale formation deep underground. Since shale hydrofracture was halted at ORNL, the LLLW has been accumulating in tanks that are now nearly full. This waste is a particular concern because no treatment process is immediately available for its disposal. Many options have been examined to relieve the short-term problem, which is 
inadequate liquid waste storage capacity, and to properly deal with the material in the longer term.

As new regulations have been adopted, requiring ever-increasing decontamination factors (DFs) for dis charge of PW, a series of flowsheets has been applied, based on different combinations of filtration, scavenging precipitation, water softening, and ion-exchange with either Duolite CS-100 or a strong-acid resin. These processes produced two liquid wastes: (1) the resin regenerant solution that was initially disposed of via shale hydrofracture and is presently concentrated and stored in LLLW tanks, and (2) a lowactivity clarification sludge that is currently filtered and stored in drums. A simpler process has been developed for application in a few years, based on inorganic ion-exchangers (zeolites) that remove both strontium and cesium and can be disposed of directly without elution, thereby removing this source of liquid waste. In the meantime, simple modifications to improve the DF of the current process are under study.

In chemical separations processes for cesium, the primary interferences are usually other alkali metals, especially the heavier ones. In this case, sodium is in very high concentration and potassium is significant $(\sim 0.25 \underline{\mathrm{M}})$. Therefore, depending on the particular process, sodium and potassium tend to control cesium removal. Good cesium separations have been accomplished with zeolites [notably at Three Mile Island], ${ }^{1}$ phenolic ion-exchangers like Duolite CS-100, and tetraphenyl borate. The transition metal hexacyanoferrate(II) compounds (ferrocyanides) have been studied extensively and are used especially in Europe ${ }^{2}$ in addition, there are several other inorganic ion-exchangers that might be useful. This study focused on nicke! and cobalt ferrocyanides and on organic ion-exchange resins based on phenol and resorcinol.

To a greater extent, alkaline earth elements interfere with strontium removal; therefore, the recovery of ${ }^{90} \mathrm{Sr}$ from waste solutions is more difficult because the alkaline earth metals are not easily separated. As a result, removal of trace ${ }^{90} \mathrm{Sr}$ generally requires removal of bulk calcium, which may require much more ion-exchange material and, thus, gencrate more

solid waste. I. some systems the high sodium concentration limits ${ }^{90} \mathrm{Sr}$ recovery, but several ion-exchangers are selective for the divalent alkaline earth elements over sodium. In this work, chelating resins and sodium titanate are being studied.

\section{CESIUM REMOVAL INTTH HEXACYANOFERRATE(II) COMPOUNDS}

The ferrocyanides are readily prepared by mixing solutions of sodium or potassium ferrocyanide with a transition metal such as $\mathrm{Co}\left(\mathrm{NO}_{3}\right)_{2}$ or $\mathrm{Ni}\left(\mathrm{NO}_{3}\right)_{2} \cdot{ }^{3}$ A precipitate forms 
that often is nonstoichiometric, the composition depending on the method of preparation. The compound can be represented as $\mathrm{A}_{2 \mathrm{x}} \mathrm{M}_{2 \cdot \mathrm{x}} \mathrm{Fe}(\mathrm{CN})_{6}$, where $\mathrm{A}$ is an alkali metal (sodium, potassium), $M$ is a transition metal (cobalt, nickel, zinc, etc.), and $x$ can vary between 0 and 1; the abbreviation AMFCN will be used here. The precipitates tend to be very small crystals with pores containing water of hydration. They are remarkably stable chemically, withstanding even high concentrations of nitric acid and concentrated salt solutions but decomposing at pHs $>-11$. Cesium will exchange into the crystal, replacing the alkali metal and part of the transition metal.

The ferrocyanides can be introduced as preformed slurries prepared by mixing solutions of the ferrocyanide and transition metal in the specified ratio, or the precipitate can be formed in situ by the addition of the two reagents to the waste solution, along with a $\mathrm{pH}$ adjustment or head-end pretreatment. The result may be different, depending on whether the ferrocyanide or metal is added first. Sedimentation characteristics and the ease of clarification vary greatly, depending on many factors, including the preparation method and aging. With some compositions, a hard, granular product can be prepared. This can have two advantages: (1) it is suitable for use in a column, and (2) it may be more resistant to high-pH solutions.

Typical results from tests with a waste simulant solution are shown in Table 2 . The $\mathrm{pH}$ was adjusted to 6.5 , and $\mathrm{KCoFCN}$ was precipitated in situ by adding potassium ferrocyanide followed by cobalt nitrate to give $\sim 110 \mathrm{pp} n$ of the compound. In the first test, $>99 \%$ of the ${ }^{137} \mathrm{Cs}$ was removed at all mixing times from $11 \mathrm{~min}$ to $7 \mathrm{~d}$. The distribution coefficient $\left[\mathrm{K}_{\mathrm{d}}=\mathrm{V}\left(\mathrm{C}_{0}-\mathrm{C}\right) / \mathrm{mC}\right.$, where $\mathrm{V}$ is the solution volume, $\mathrm{m}$ is the exchanger mass, and $\mathrm{C}_{0}$ and $\mathrm{C}$ are the concentrations before and after mixing] was usually $>10^{6}$. The experiment was repeated, and ${ }^{137} \mathrm{Cs}$ removal was considerably smailer in the first three measurements. It was noted that crystals appeared in the bottom of some samples after they had been left standing for a day, so centrifugation had not removed all the solids. When the solution was clarified in a more effective manner, either by recentrifuging the sample or by filtering with a $0.2-\mu \mathrm{m}$ filter, $>99 \%{ }^{137} \mathrm{Cs}$ removal was obtained.

Similar tests were performed under a range of conditions, and the initial data showed considerable scatter, as in Table 2, because of incomplete solids separation. As long as good clarification was achieved, ${ }^{137} \mathrm{Cs}$ decontamination was very large. Values of $\mathrm{K}_{\mathrm{d}}$ were unusually large for an ion-exchange process, and in many cases, the measurements indicated the efficiency of solids removal instead of the selectivity of the ferrocyanide for cesium. 
Table 2. Cesium removal with $\mathrm{KCoFCN}^{2}$

\begin{tabular}{cccc}
\hline $\begin{array}{l}\text { Mix } \\
\text { Time }\end{array}$ & $\begin{array}{c}\text { Clarification } \\
\text { Method }^{\mathrm{b}}\end{array}$ & $\begin{array}{c}\text { Percentage of } \\
\text { Cesium Removed }\end{array}$ & $\mathrm{K}_{\mathrm{d}}$ \\
\hline $11 \mathrm{~min}$ & cent & 99.2 & $1.19 \times 10^{6}$ \\
$1 \mathrm{~h}$ & cent & 99.7 & $2.57 \times 10^{6}$ \\
$24 \mathrm{~h}$ & cent & 99.1 & $9.87 \times 10^{5}$ \\
$7 \mathrm{~d}$ & cent & 99.7 & $3.39 \times 10^{6}$ \\
$7 \mathrm{~d}$ & cent 2 & 99.85 & $6.05 \times 10^{6}$
\end{tabular}

\begin{tabular}{ccll}
\multicolumn{2}{c}{ Repeat Experiment } & & \\
\hline $10 \mathrm{~min}$ & cent & 76.8 & $3.00 \times 10^{4}$ \\
$1 \mathrm{~h}$ & cent & 70.0 & $2.13 \times 10^{4}$ \\
$24 \mathrm{~h}$ & cent & 82.9 & $4.41 \times 10^{4}$ \\
$24 \mathrm{~h}$ & cent 2 & 99.34 & $1.38 \times 10^{6}$ \\
$24 \mathrm{~h}$ & filt & 99.97 & $2.80 \times 10^{7}$
\end{tabular}

\footnotetext{
${ }^{\mathrm{a}} 110 \mathrm{ppm} \mathrm{KCoFCN}$ in simulated LLLW; $\mathrm{pH} 6.5$; $\mathrm{Co} / \mathrm{Fe}=1.7$; add ferrocyanide, then cobalt.

bent: clarified by centrifuging 10 min.; cent 2 : recentrifuged $1 \mathrm{~d}$ later; filt: filtered through $0.2-\mu \mathrm{m}$ filter.
}

At higher $\mathrm{pH},>\sim 11$, the $\mathrm{f} \in$ rrocyanides lost effectiveness. The removal of ${ }^{137} \mathrm{Cs}$ using dried, granular $\mathrm{KNiFCN}$ is shown in Table 3. Excellent results were obtained at $\mathrm{pH}$ values of 9 and 11 , even after 2 weeks. At $\mathrm{pH} 12$, however, ${ }^{137} \mathrm{Cs}$ was removed only for a short time. After $1 \mathrm{~d}$, the removal decreased to $65 \%$; after $4 \mathrm{~d}$, it was essentially zero. A number of AMFCN preparations with various heat treatments were tested, and some - notably heattreated KCoFCN - offered fairly good decontamination for a number of days at $\mathrm{pH} 12$. However, all lost effectiveness with increasing time, probably because of decomposition of the meial ferrocyanide crystal to metal hydroxide at $\mathrm{pH}>\sim 11$.

Results from a test made with actual supernate from one of the ORNL waste tanks are shown in Table 4. Several different ferrocyanides were used; and, in the first four cases, the solutions were adjusted to a lower $\mathrm{pH}, 9.6$. NaCoFCN and $\mathrm{NaNiFCN}$ at $50 \mathrm{ppm}$ were especially effective. Clarification problems caused some of the results for KCoFCN to be poor. The last column, for $21 \mathrm{~d}$, is most significant because greater care was taken to remove solids that had caused poor ${ }^{137} \mathrm{Cs}$ decontamination in some cases.

At the higher $\mathrm{pH}$ of 11.5 , good removal of ${ }^{137} \mathrm{Cs}$ was obtained with granular KCoFCN over a period up to $\sim 1 \mathrm{~d}$, but then it became less effective. At $100 \mathrm{ppm}$, it removed $<10 \%$ 
Table 3. Effect of $\mathrm{pH}$ on Cesium Removal ${ }^{2}$

\begin{tabular}{cccc}
\hline $\begin{array}{c}\text { Mixing } \\
\text { Time }\end{array}$ & \multicolumn{3}{c}{ Percentage of Cesium Removed at $\mathrm{pH}$} \\
\cline { 3 - 4 } & 9.0 & 11.0 & 12.0 \\
\hline $1 \mathrm{~h}$ & 96.63 & 93.18 & 89.9 \\
$24 \mathrm{~h}$ & 99.60 & 99.22 & 65.8 \\
$24 \mathrm{~h}$ filt. & - & 99.25 & 65.6 \\
$4 \mathrm{~d}$ & 99.86 & 99.58 & $\sim 0$ \\
$7 \mathrm{~d}$ & 99.80 & 99.50 & $\sim 0$ \\
$14 \mathrm{~d}$ & 99.81 & 99.73 & $\sim 0$
\end{tabular}

${ }^{\mathrm{a}}$ Simulated LLLW adjusted to $\mathrm{pH} ;+333 \mathrm{ppm}$ dried $\mathrm{KNiFCN}, \mathrm{Ni} / \mathrm{Fe}=1.7$

Table 4. Decontamination of LLLW supernate solution ${ }^{2}$

\begin{tabular}{|c|c|c|c|c|c|}
\hline \multirow{2}{*}{$\frac{\text { Sorbent }}{\text { PPM FCN }}$} & \multirow{2}{*}{$\begin{array}{l}\text { LLLW } \\
\mathrm{pH}\end{array}$} & \multicolumn{3}{|c|}{ Mixing Time } & \multirow[b]{2}{*}{$21 \mathrm{~d}^{\mathrm{c}}$} \\
\hline & & $15 \mathrm{~m}$ & $4 \mathrm{~h}$ & $24 \mathrm{~h}$ & \\
\hline & & \multicolumn{3}{|c|}{ Percentage of Cesium Removed } & \\
\hline $50 \mathrm{NaCo}-\mathrm{S}$ & 9.60 & $\overline{83.8}$ & 96.7 & 99.0 & 99.5 \\
\hline $50 \mathrm{NaNi}-\mathrm{S}$ & 9.60 & 77.9 & 93.4 & 97.5 & 99.3 \\
\hline $50 \mathrm{KCo}-\mathrm{S}$ & 9.60 & 23.0 & 49.1 & 88.3 & 97.6 \\
\hline $150 \mathrm{KCo}-\mathrm{S}$ & 9.60 & 66.4 & 92.4 & 99.0 & 99.7 \\
\hline $100 \mathrm{KCo}-\mathrm{G}$ & 11.5 & 83.8 & 95.5 & 87.2 & 8.4 \\
\hline $500 \mathrm{KCo}-\mathrm{G}$ & 11.5 & 94.3 & 98.0 & 95.6 & 55.5 \\
\hline & & \multicolumn{3}{|c|}{ Percentage of Strontium Removed } & \\
\hline $\begin{array}{ll}500 & \text { KCo-G } \\
500 & +\mathrm{NaT} \\
\end{array}$ & 11.5 & 58.2 & 92.2 & 97.3 & 99.5 \\
\hline
\end{tabular}


after $21 \mathrm{~d}$; and at $500 \mathrm{ppm},-50 \%$. In the last case, $500 \mathrm{ppm}$ of sodium titanate was also added, and ${ }^{85} \mathrm{Sr}$ was effectively removed. These experiments demonstrate that $>99 \%$ of both ${ }^{137} \mathrm{Cs}$ and ${ }^{85} \mathrm{Sr}$ can be removed from this low-level waste with a single-stage batch separation.

These methods have also been applied to the process waste. The discharge limit for ${ }^{137} \mathrm{Cs}$ is currently being reduced, so that an additional DF of -5 will be required to bring the large-volume $\mathrm{PW}$ stream into compliance. Some tests were made in which small quantities of ferrocyanides were added during the softening-clarification step of the present process (Table 5). Additions of NaNiFCN were most effective, with even $3 \mathrm{ppm}$ giving an adequate DF. Nearly all the tests except the blanks gave useful DFs.

Table 5. ${ }^{137} \mathrm{Cs}$ removal from process waste

\begin{tabular}{|c|c|c|c|c|}
\hline \multicolumn{2}{|c|}{ Sorbent } & \multicolumn{2}{|c|}{ Conc. $(\mathrm{Bg} / \mathrm{L})$} & \multirow[b]{2}{*}{ DF } \\
\hline PPM & $\mathrm{FC} \mathrm{N}^{\mathrm{b}}$ & Feed & Supernate & \\
\hline 100 & $\mathrm{KCo}-\mathrm{G}$ & 90. & 3.1 & 61. \\
\hline 100 & $\mathrm{KCO}-\mathrm{G}$ & 141. & 1.6 & 88. \\
\hline 20 & $\mathrm{KCo}-\mathrm{G}$ & 61. & 2.9 & 21. \\
\hline 20 & $\mathrm{KCo}-\mathrm{S}^{\mathrm{c}}$ & 141. & 11. & 13. \\
\hline 20 & $\mathrm{KNi}-\mathrm{S}$ & 141. & 2.8 & 50. \\
\hline 3 & $\mathrm{KNi}-\mathrm{S}$ & 100. & 1.9 & 54. \\
\hline 20 & $\mathrm{NaNi}$-S & 100. & 2.1 & 49. \\
\hline 3 & $\mathrm{NaNi}-\mathrm{S}$ & 141. & 8. & 17. \\
\hline 20 & $\mathrm{NaCo}-\mathrm{S}$ & 141. & 19. & 7. \\
\hline 0 & Blank & 141. & 114. & 1.2 \\
\hline 0 & Blank & 190. & 150. & 1.3 \\
\hline
\end{tabular}

\section{PROCESS APPLICATION}

Simple batch processes ususally generate more solid waste (sludge) than multistage colurnn operations and give smaller DFs, often in the vicinity of 10 ; therefore, multistage column processes are usually required to obtain large DFs. In this case, the ${ }^{137} \mathrm{Cs} \mathrm{K}_{\mathrm{d}} \mathrm{s}$ are so large, $10^{5}$ to $10^{6}$, that a batch process can provide DFs in the range of thousands while generating a reasonably small volume of solid waste. Two or three batch separation stages can yield a very efficient process. This opens the possibility of achieving large DFs using methods common to bulk water treatment, instead of multistage processes such as 
ion-exchange columns. The very large theoretical column capacities, resulting from the large $\mathrm{K}_{\mathrm{d}} \mathrm{s}$, generally cannot be realized in practice because of mechanical problems.

A single-stage process, such as a clarifier, in which a ferrocyanide and sodium titanate are added along with other chemicals for feed adjustment and clarification (i.e., ferric hydroxide scavenging precipitation), can effectively remove actinides, rare earths, ${ }^{90} \mathrm{Sr}$, and ${ }^{137}$ Cs. Depending on conditions, the clarified and decontaminated product water from such a process could be furthertreated (e.g., with ion-exchange columns), stored, solidified, or possibly discharged to the environment.

A more effective flowsheet, in which two stages of separation are obtained by adding the reagents to a second-stage mixer that feeds an ultrafilter, is shown in Fig. 1. The concentrate from the ultrafilter would be back-cycled to the first-stage clarifier, where the solid product is removed as a sludge. Such a process should give substantially better performance-a larger DF and a smaller reagent requirement. An ultrafilter is included because removal of colloidal material may be necessary to achieve the large DFs potentially available.

\section{CESIUM AND STRONTIUM REMOVAL WITH ORGANIC ION-EXCHANGE RESINS}

Approximately $1 \mathrm{~L}$ of resorcinol-based ion-exchange resin was provided by the Savannah River Site (designated as SRS resin), ${ }^{4}$ and a portion was washed and segregated into narrow size fractions. Duolite CS-100 was obtained previously from Rohm and Haas. The resins were prepared for column tests by washing twice with 10 resin volumes (CV) of $2 \underline{\mathrm{M}}$ formic

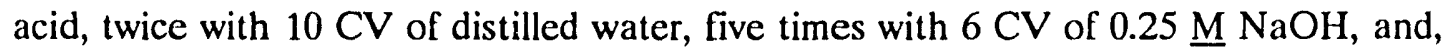
finally, three times with $10 \mathrm{CV}$ of distilled water. The washed resin was dried by placing it on blotter paper at room temperature overnight. Weighed samples of this resin were used for batch $\mathrm{K}_{\mathrm{d}}$ tests. For column tests, a volume of resin was measured, placed into the column, and rehydrated.

\subsection{BATCH $\mathrm{K}_{d}$ EXPERIMENTS}

Cation-exchange equilibria in systems containing ${ }^{137} \mathrm{Cs}$ and ${ }^{85} \mathrm{Sr}$ tracers in LLLW simulant composition were obtained using batch equilibration techniques at the conditions shown below. Combinations of the following variables were used:

1. simulant to water dilutions of $0,3: 1,3: 5$, and $1: 7$;

2. initial feed pHs adjusted to $11,12,12.5,13$, and 13.3; 
?. potassium concentrations of $0,0.05,0.1,0.25$, and $0.5 \underline{\mathrm{M}}$ : and

4. equilibration times of $1,24,48$, and 90 or $96 \mathrm{~h}$.

The experiments used $15 \mathrm{~mL}$ of solution (initial) along with $100 \mathrm{mg}$ of dry $60-80$ mesh sodium-form SRS resin. The $\mathrm{pH}$ of the liquid was measured before and after equilibrium contact, and it usually decreased by 0.1 to $0.3 \mathrm{pH}$ units, with the greater decrease at the lower salt concentrations.

Some of the results are summarized in Table 6 . For ${ }^{137} \mathrm{Cs}$, the most favorable $\mathrm{K}_{\mathrm{d}} \mathrm{s}$ are obtained at $\mathrm{pH} \sim 12.5$ in nearly all cases, and the sodium concentration had little effect when potassium was present. The $K_{d}$ was approximately inversely proportional to the potassium concentration, varying from $\sim 800$ for $0.5 \underline{\mathrm{M}}$ potassium to 20,000 with no potassium at $\mathrm{pH} 12.5$.

Strontium $K_{d} s$ were primarily dependent on the sodium concentration and independent of the potassium concentration except when the sodium concentration was lowest; in that case, the dependence may be on the total alkali metal concentration. They were somewhat higher at the higher $\mathrm{pH}$ values. The ${ }^{85} \mathrm{Sr} \mathrm{K}_{d} \mathrm{~s}$ ranged from $\sim 175$ for undiluted simulant to $\sim 2000$ for the highest dilution. In all cases except for the high potassium and lowest sodium concentrations, the $\mathrm{K}_{d}$ for ${ }^{85} \mathrm{Sr}$ was less than that for ${ }^{137} \mathrm{Cs}$, confirming that ${ }^{90} \mathrm{Sr}$ should break through before ${ }^{137} \mathrm{Cs}$, in many cases by as much as a factor of 10 . As a general rule, the capacity of an ion-exchange column (liters processed per kilogram of resin) is somewhat less, at best, than the $K_{d}$ value in the same units.

Measurements of the $\mathrm{K}_{\mathrm{d}}$ values for ${ }^{137} \mathrm{Cs}$ and ${ }^{85} \mathrm{Sr}$ for $\mathrm{CS}-100$ resin were made at a pH of 12.5 in LLLW simulant at sodium concentrations of $0.57,1.82,3.49$, and $4.58 \mathrm{M}$ and potassium concentrations of $0,0.05,0.1,0.25$, and $0.5 \underline{\mathrm{M}}$ for comparison with the SRS resin. These results are shown in Table 7. The $\mathrm{K}_{d} \mathrm{~s}$ for ${ }^{85} \mathrm{Sr}$ ard ${ }^{137} \mathrm{Cs}$ ranged from -200 and 28 , respectively, at $4.58 \underline{\mathrm{M}} \mathrm{Na}-0.5 \underline{\mathrm{M}}$ potassium to -5100 and 490 at $0.57 \underline{\mathrm{M}}$ sodium. While potassium had little effect on the ${ }^{85} \mathrm{Sr} \mathrm{K}$, it had a substantial effect on the ${ }^{137} \mathrm{Cs} \mathrm{K}_{\mathrm{J}}$. The CS-100 resin was generally comparable to the SRS resin for ${ }^{85} \mathrm{Sr}$ removal but was quite inferior for ${ }^{137} \mathrm{Cs}$ removal. The result for a column design is that ${ }^{137} \mathrm{Cs}$ removal limits the maximum throughput with CS-100, and ${ }^{85} \mathrm{Sr}$ removal limits the throughput with SRS resin. If both elements are present, the smaller $\mathrm{K}_{\mathrm{d}}$ (lower breakthrough capacity) always occurs with CS-100. 


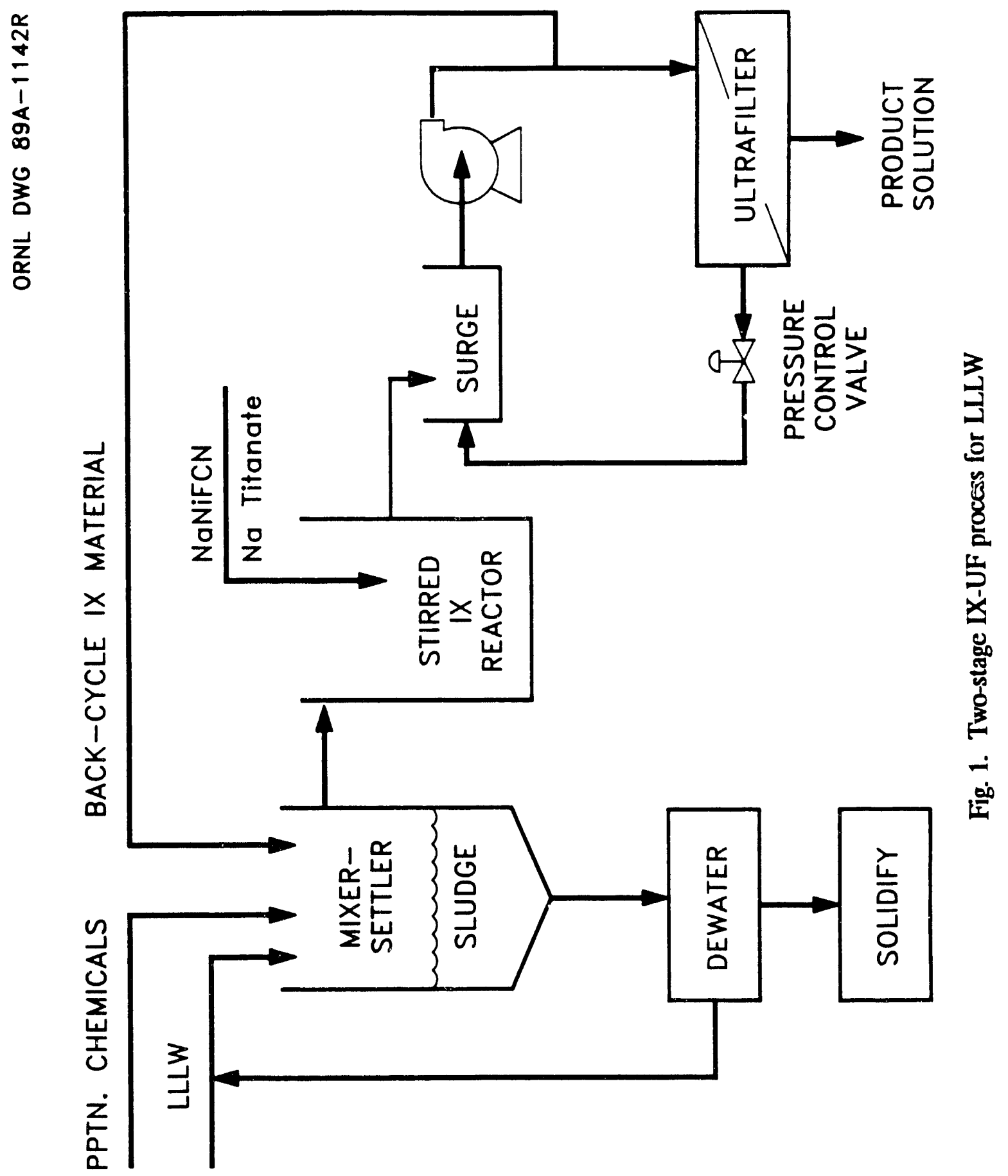


Table 6. Comparison of batch $\mathrm{K}_{\mathrm{d}}$ data for SRS resin for various potassium, sodium, and $\mathrm{pH}$ conditions

\begin{tabular}{|c|c|c|c|c|c|c|c|c|c|}
\hline \multirow[b]{3}{*}{$\mathrm{pH}$} & \multirow[b]{3}{*}{$K(\underline{M})$} & \multicolumn{4}{|c|}{ Strontium $\mathrm{K}_{\mathrm{d}} \mathrm{s}$} & \multicolumn{4}{|c|}{ Cesium $K_{d}$ S } \\
\hline & & I & \multicolumn{3}{|c|}{ sodium $(\underline{M})$} & & \multicolumn{2}{|c|}{ sodium (M) } & \multirow[b]{2}{*}{0.57} \\
\hline & & 14.58 & 3.44 & 1.72 & 0.57 & 4.58 & 3.44 & 1.72 & \\
\hline 11.0 & 0.5 & 50 & 75 & 175 & 587 & 356 & 352 & 332 & 272 \\
\hline 12.0 & 0.5 & 64 & 87 & 218 & 666 & 588 & 623 & 662 & 594 \\
\hline 12.5 & 0.5 & | 167 & 229 & 395 & 660 & 797 & 851 & 923 & 638 \\
\hline 13.0 & 0.5 & | 176 & 240 & 531 & 1524 & 640 & 645 & 750 & 852 \\
\hline 13.3 & 0.5 & 175 & 244 & 534 & 1436 & 562 & 599 & 689 & 756 \\
\hline 11.0 & 0.25 & 47 & 74 & 202 & 824 & 502 & 538 & 523 & 435 \\
\hline 12.0 & 0.25 & 67 & 104 & 258 & 996 & 955 & 987 & 1107 & 1047 \\
\hline 12.5 & 0.25 & 178 & 223 & 462 & 1063 & 1212 & 1284 & 1634 & 1135 \\
\hline 13.0 & 0.25 & 183 & 254 & 618 & 2164 & 990 & 1116 & 1342 & 1620 \\
\hline 13.3 & 0.25 & 179 & 255 & 535 & 1784 & 993 & 1020 & 1263 & 1477 \\
\hline 11.0 & 0.1 & 44 & 76 & 222 & 1106 & כואי & 090 & 929 & 822 \\
\hline 12.0 & 0.1 & 69 & 104 & 283 & 1335 & 1649 & 1776 & 2068 & 2109 \\
\hline 12.5 & 0.1 & | 181 & 244 & 527 & 1378 & 2235 & 2524 & 3051 & 2283 \\
\hline 13.0 & 0.1 & | 187 & 269 & 608 & 2572 & 1830 & 1859 & 2866 & 3595 \\
\hline 13.3 & 0.1 & | 183 & 255 & 566 & 2050 & 1693 & 1970 & 2308 & 3333 \\
\hline 11.0 & 0.05 & 48 & 70 & 232 & 1246 & 1053 & 95 & 1306 & 1241 \\
\hline 12.0 & 0.05 & 71 & 106 & 293 & 1528 & 2141 & 2410 & 3170 & 3442 \\
\hline 12.5 & 0.05 & 186 & 198 & 526 & 1481 & 3334 & 3857 & 4744 & 3366 \\
\hline 13.0 & 0.05 & 188 & 279 & 597 & 2513 & 2445 & 2986 & 3642 & 5617 \\
\hline 13.3 & 0.05 & 184 & 263 & 600 & 2049 & 2375 & 2886 & 3674 & 5315 \\
\hline 11.0 & 0.0 & 47 & 79 & 209 & 1446 & 1963 & 2740 & 3771 & 5475 \\
\hline 12.0 & 0.0 & 73 & 115 & 298 & 1723 & 4369 & 5607 & 8920 & 17425 \\
\hline 12.5 & 0.0 & 175 & 244 & 519 & 1700 & 7532 & 9478 & 18300 & 20818 \\
\hline 13.0 & 0.0 & 184 & 282 & 664 & 2723 & 5088 & 8078 & 11248 & 32408 \\
\hline 13.3 & 0.0 & 188 & 271 & 620 & 2294 & 5008 & 6755 & 12688 & 25282 \\
\hline
\end{tabular}


Table 7. Comparison of CS-100 and SRS resins

\begin{tabular}{|c|c|c|c|c|c|c|c|c|c|c|}
\hline \multirow{2}{*}{\multicolumn{2}{|c|}{$\underline{\mathrm{K}}(\mathrm{M}) \mathrm{Na}(\mathrm{M})$}} & \multicolumn{5}{|c|}{ CS-100 Resin } & \multicolumn{4}{|c|}{ SRS Resin } \\
\hline & & $\frac{1 \mathrm{~h}}{{ }^{85} \mathrm{Sr}}$ & $90 \mathrm{~h}$ & & 11 & $\frac{90 \mathrm{~h}}{\mathrm{~s} \mathrm{~K}_{\mathrm{d}}}$ & $\frac{1 \mathrm{~h}}{85}$ & $\frac{90 \mathrm{~h}}{\mathrm{~K}_{\mathrm{d}}}$ & $\frac{1 \mathrm{~h}}{137 \mathrm{C}}$ & $\frac{90 \mathrm{~h}}{\mathrm{~K}_{\mathrm{d}}}$ \\
\hline 0.50 & 4.58 & 62 & 198 & | & 20 & 28 & 112 & 167 & 161 & 797 \\
\hline 0.25 & 4.58 & 75 & 208 & & 25 & 38 & 113 & 178 & 192 & 1212 \\
\hline 0.10 & 4.58 & 61 & 211 & | & 25 & 46 & 113 & 181 & 250 & 2235 \\
\hline 0.05 & 4.58 & 66 & 202 & 1 & 31 & 55 & 115 & 186 & 283 & 3.334 \\
\hline & 4.58 & 72 & 208 & | & 39 & 77 & 113 & 175 & 351 & 7532 \\
\hline 0.50 & 3.49 & 113 & 291 & | & 26 & 32 & 173 & 229 & 259 & 851 \\
\hline 0.2 & 3.49 & 103 & 298 & | & 30 & 42 & 153 & 223 & 297 & 1284 \\
\hline 0.1 & 3.49 & 121 & 329 & | & 38 & 55 & 162 & 244 & 415 & 2524 \\
\hline 0.05 & 3.49 & 121 & 311 & 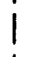 & 47 & 68 & 123 & 198 & 322 & 3857 \\
\hline & 3.49 & 124 & 313 & & 64 & 103 & 167 & 244 & 676 & 9478 \\
\hline 0.50 & 1.82 & 313 & 700 & 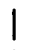 & 37 & 42 & 342 & 395 & 438 & 923 \\
\hline 0.25 & 1.82 & 344 & 777 & 1 & 56 & 66 & 363 & 462 & 643 & 1634 \\
\hline 0.10 & 1.82 & 313 & 847 & 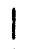 & 65 & 91 & 388 & 527 & 1032 & 3051 \\
\hline 0.05 & 1.82 & 333 & 792 & 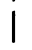 & 83 & 110 & 399 & 526 & 1244 & 4744 \\
\hline & 1.82 & 391 & 888 & & 134 & 198 & 402 & 519 & 2009 & 18300 \\
\hline 0.50 & 0.57 & 1053 & 2514 & & 48 & 58 & 989 & 660 & 648 & 638 \\
\hline 0.25 & 0.57 & 1346 & 3332 & 1 & 77 & 99 & 1298 & 1063 & 1091 & 1135 \\
\hline 0.10 & 0.57 & 1625 & 3557 & & 120 & 148 & 1664 & 1378 & 2066 & 2283 \\
\hline 0.05 & 0.57 & 1872 & 4311 & & 163 & 210 & 1811 & 1481 & 2776 & 3366 \\
\hline 0 & 0.57 & 1682 & 5099 & & 304 & 491 & 2046 & 1700 & 7864 & 20818 \\
\hline
\end{tabular}

\subsection{ION-EXCHANGE COLUMN TESTS}

Several column tests were completed using LLLW simulant and 3 to $5 \mathrm{~mL}$ of SRS resin. Conditions for these runs are shown in Table 8. Preliminary ion-exchange column tests with SRS resin were unsuccessful because a precipitate coated the resin particles. The source of this problem is believed to be aluminum, which becomes less soluble as the $\mathrm{pH}$ is decreased. In some runs, the $\mathrm{pH}$ of the simulant decreased by 1 to $1.5 \mathrm{pH}$ units upon contact with fresh resin. It is, therefore, necessary to maintain a high $\mathrm{pH}$ during column runs. A $1 \underline{\mathrm{M}} \mathrm{NaOH}$ solution was passed through the column just before introducing the feed to prevent an initial decrease in $\mathrm{pH}$. Using this procedure, almost no solids were observed in the columns or on the resin particles, and no significant increase in pressure drop was noted.

The ${ }^{137} \mathrm{Cs}$ breakthrough curves indicated rather slow kinetics, with $1 \%$ breakthrough at $\sim 40 \mathrm{CV}$ and a $\mathrm{K}_{d}^{\prime}$ of $\sim 750$ (SRL1). Volumetric distribution coefficients ( $\mathrm{K}_{d}^{\prime} \mathrm{s}$ ) were obtained from a probability-log graph of $\mathrm{C} / \mathrm{C}_{0}(\%)$ vs the column throughput $(\mathrm{CV}){ }^{5}$ The $\mathrm{CV}$ at $50 \% \mathrm{C} / \mathrm{C}_{0}$ is approximately the $\mathrm{K}_{\mathrm{d}}^{\prime}$. When the feed $\mathrm{pH}$ was increased to 13.8 by 
Table 8. Data for SRS resin column runs

\begin{tabular}{lccccc}
\hline Run & $\begin{array}{c}\text { Sodium } \\
(\mathrm{M})\end{array}$ & $\mathrm{pH}$ & $\begin{array}{c}\text { Potassium } \\
(\mathrm{M})\end{array}$ & $\begin{array}{c}\text { Size } \\
(\mu \mathrm{m})\end{array}$ & $\begin{array}{c}\text { Flow } \\
(\mathrm{cm} / \mathrm{min})\end{array}$ \\
\hline SRL1 & 4.58 & 13.3 & 0.25 & 210. & 1.067 \\
SRL2 & 5.06 & 13.8 & 0.25 & 210. & 1.30 \\
NaK1 & 4.70 & 13.2 & 0.25 & 210. & 1.28 \\
SRL3 & 4.58 & 12.8 & 0.25 & 210. & 0.26 \\
SRL4 & 4.58 & 13.2 & 0.25 & 115. & 1.26 \\
SRL5 & 4.58 & 13.2 & 0.50 & 115. & 1.26 \\
SRL6 & 4.58 & 13.2 & 0.10 & 115. & 1.24 \\
SRL7 & 0.95 & 12.65 & 0.052 & 115. & 1.20 \\
Na1 & 4.45 & 13.2 & 0.0 & 210. & 1.28 \\
\hline
\end{tabular}

adding $\mathrm{NaOH}$ to make the solution $0.7 \underline{\mathrm{M}}$ in $\mathrm{NaOH}$ (SRL2), the ${ }^{137} \mathrm{Cs}$ breakthrough occurred more rapidly. Test SRL3 using the LLLW simulant at $20 \%$ of the earlier flow rate through the column $(0.26 \mathrm{~cm} / \mathrm{min}$ vs $1.3-\mathrm{cm} / \mathrm{min}$ superficial velocity) resulted in a breakthrough curve that was much steeper, not beginning to rise until $-225 \mathrm{CV}$ compared with the continuous rise in the earlier (SRL1 and SRL2) simulant tests. The 50\% breakthrough occurred at $759 \mathrm{CV}$, as in the earlier tests. Run Na1 used feed consisting only of $4.45 \underline{\mathrm{M}} \mathrm{NaNO}_{3}$ plus a spike of LLLW supernate (no aluminum, calcium, zinc, potassium, or carbonate) and showed a high capacity $\left(\mathrm{K}_{d}^{\prime} \sim 7300\right)$. Addition of $0.25 \underline{\mathrm{M}}$ $\mathrm{KNO}_{3}$ to $\mathrm{NaNO}_{3}$ in run NaK1 caused a decrease in $\mathrm{K}_{d}^{\prime}$ to nearly that of the LLLW simulant containing all of the components $\left(K_{d}^{\prime} \sim 690\right.$ for NaK1 vs $\sim 760$ for SRL1 and SRL3). This relative behavior is about as expected. As with the batch $K_{d}$ measurements, competition from potassium is the key limitation in the cesium removal capacity of this resin.

The feeds for runs SRL4 through SRL7 had the same composition as LLLW simulant, except that the potassium concentration was varied to $0.1,0.25$, and $0.5 \underline{\mathrm{M}}$. Also, a 3.8:1 dilution of the LLLW simulant (yielding $0.052 \underline{\mathrm{M}}$ potassium and $0.95 \underline{\mathrm{M}}$ sodium) was tested (SRL7). These runs used the same batch of 120 to 140 mesh resin $(0.115-\mathrm{mm}$ average diameter) and roughly the same flow-rate and resin-bed dimensions. The capacity of the resin bed for ${ }^{137} \mathrm{Cs}$ in runs SRL4 through SRL7 (Fig. 2) varied approximately inversely with the potassium concentration. The value of $\mathrm{K}_{\mathrm{d}}^{\prime}$ increased from 219 at $0.5 \underline{\mathrm{M}}$ potassium 


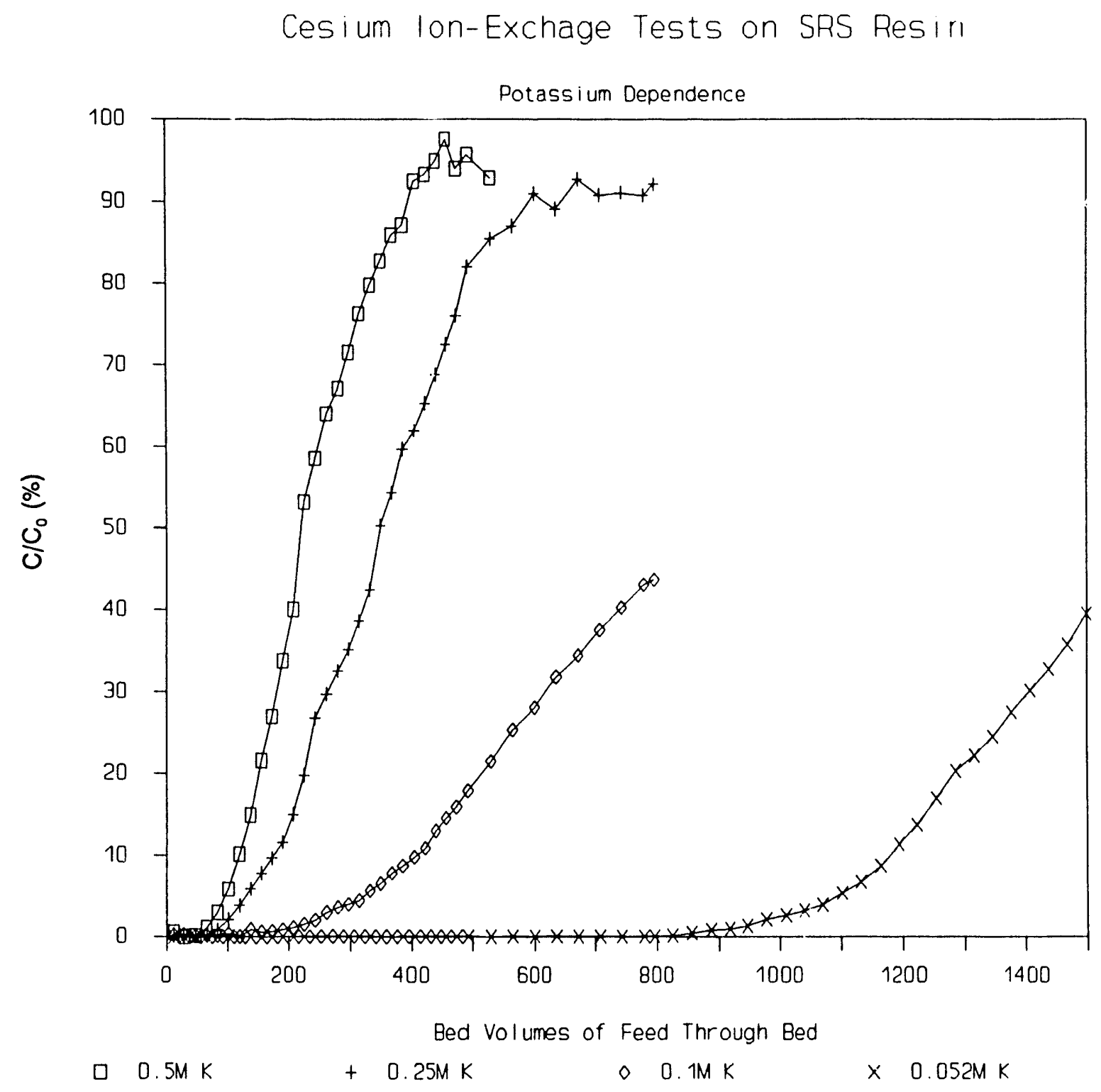

Fig. 2. Effect of potassium on cesium breakthrough curves 
to 876 at 0.1 M potassium, and was 1587 with the dilute feed. Compared with SRL1, which used a larger particle size and a different batch of simulant than SRL4, the breakthrough curves were sharper but occurred earlier.

Strontium-85 was also used as a tracer in runs SRL4 through SRL7 to study the breakthrough and loading characteristics for strontium on SRS resin under LLLW conditions. The ${ }^{85} \mathrm{Sr}$ uptake remained almost constant with a $\mathrm{K}_{\mathrm{d}}^{\prime}$ of 94 to 102 over the range of 0.1 to $0.5 \underline{\mathrm{M}}$ potassium at $4.58 \underline{\mathrm{M}}$ sodium. The $\mathrm{K}_{\mathrm{d}}^{\prime}$ increased to 4.33 with the diluted simulant. Once ${ }^{85} \mathrm{Sr}$ broke through the column, its concentration rose to a value significantly above that of the feed (Fig. 3). It appears that some ion in the LLLW simulant selectively displaced ${ }^{85} \mathrm{Sr}$ from the resin.

\subsection{RESIN ELUTION}

The resins evaluated in the column tests were eluted with formic, hydrochloric, and nitric acids at various concentrations and using different procedures. Initially for ${ }^{137} \mathrm{Cs}$ removal, 2 M formic acid was used as the eluent, and 50 to $80 \mathrm{CV}$ were required to elute all of the ${ }^{137} \mathrm{Cs}$ activity. In a second method, $3 \mathrm{CV}$ of $4 \underline{\mathrm{M}}$ formic acid followed by $30 \mathrm{CV}$ of $0.5 \underline{\mathrm{M}}$ nitric acid resulted in the elution of only $75 \%$ of the bound ${ }^{137} \mathrm{Cs}$ activity. In a third test, 12 $\mathrm{CV}$ of $4 \underline{\mathrm{M}}$ formic acid were followed by $8 \mathrm{CV}$ of $0.5 \underline{\mathrm{M}}$ nitric acid, but only $56 \%$ of the ${ }^{137} \mathrm{Cs}$ activity was eluted. Elution with $4 \underline{\mathrm{M}} \mathrm{HCl}$ resulted in $\sim 100 \%{ }^{137} \mathrm{Cs}$ activity removal in $11 \mathrm{CV}$, and counting of the eluted resin showed very little remaining activity. Examples of the elution curves for cesium and cesium and strontium are shown in Fig. 4. It was possible to account for only about $70 \%$ of the ${ }^{85} \mathrm{Sr}$ that had apparently loaded. However, because of the increase in the ${ }^{85} \mathrm{Sr}$ content of the exit stream above the feed concentration during later stages in the run, the total ${ }^{85} \mathrm{Sr}$ on the resin at the end of the run is subject to some uncertainty.

\subsection{DATA ANALYSIS}

The data were analyzed in two different ways for computing the $K_{d}^{\prime}$ values. In the lïst method, $K_{d}^{\prime}$ was determined graphically, as described previously.

The second method was one used by Doulah and Jafar ${ }^{6}$ in which the relationship between the concentration $\mathrm{C}$ at time $\Theta$ is expressed by a breakthrough function given by

$$
\mathrm{C} / \mathrm{C}_{0}=\exp \left[-\left(\left(\Theta-\Theta_{0}\right) / \Theta_{\mathrm{n}}\right)^{\mathrm{b}}\right] \text {, }
$$

where

$$
\begin{aligned}
& \Theta=\text { time (proportional to volume fed), } \\
& \Theta_{0}=\text { time to breakpoint (when } C / C_{0} \text { becomes greater than } 0.05 \text { ), }
\end{aligned}
$$




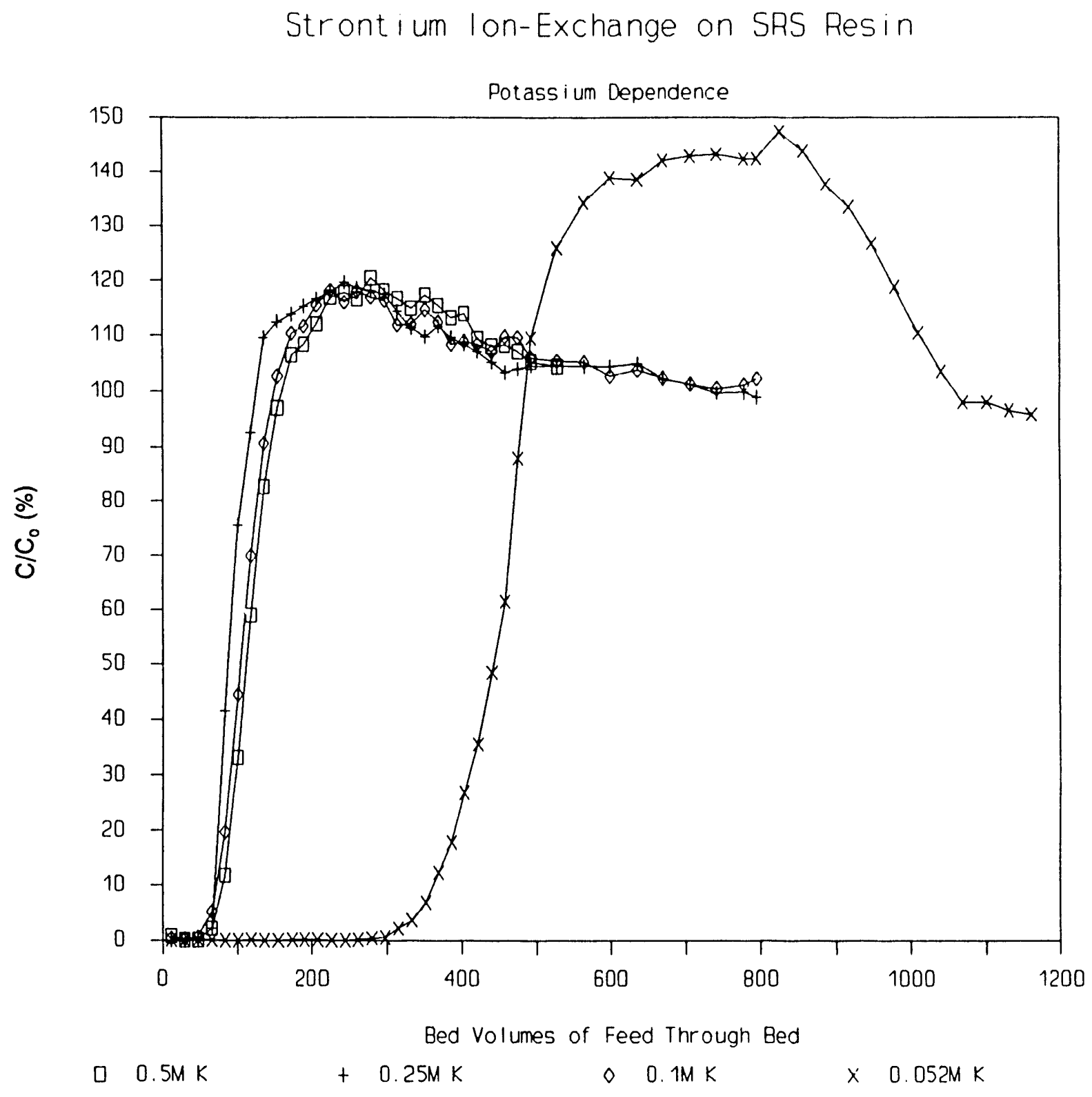

Fig. 3. Effect of potassium on strontium breakthrough curves 


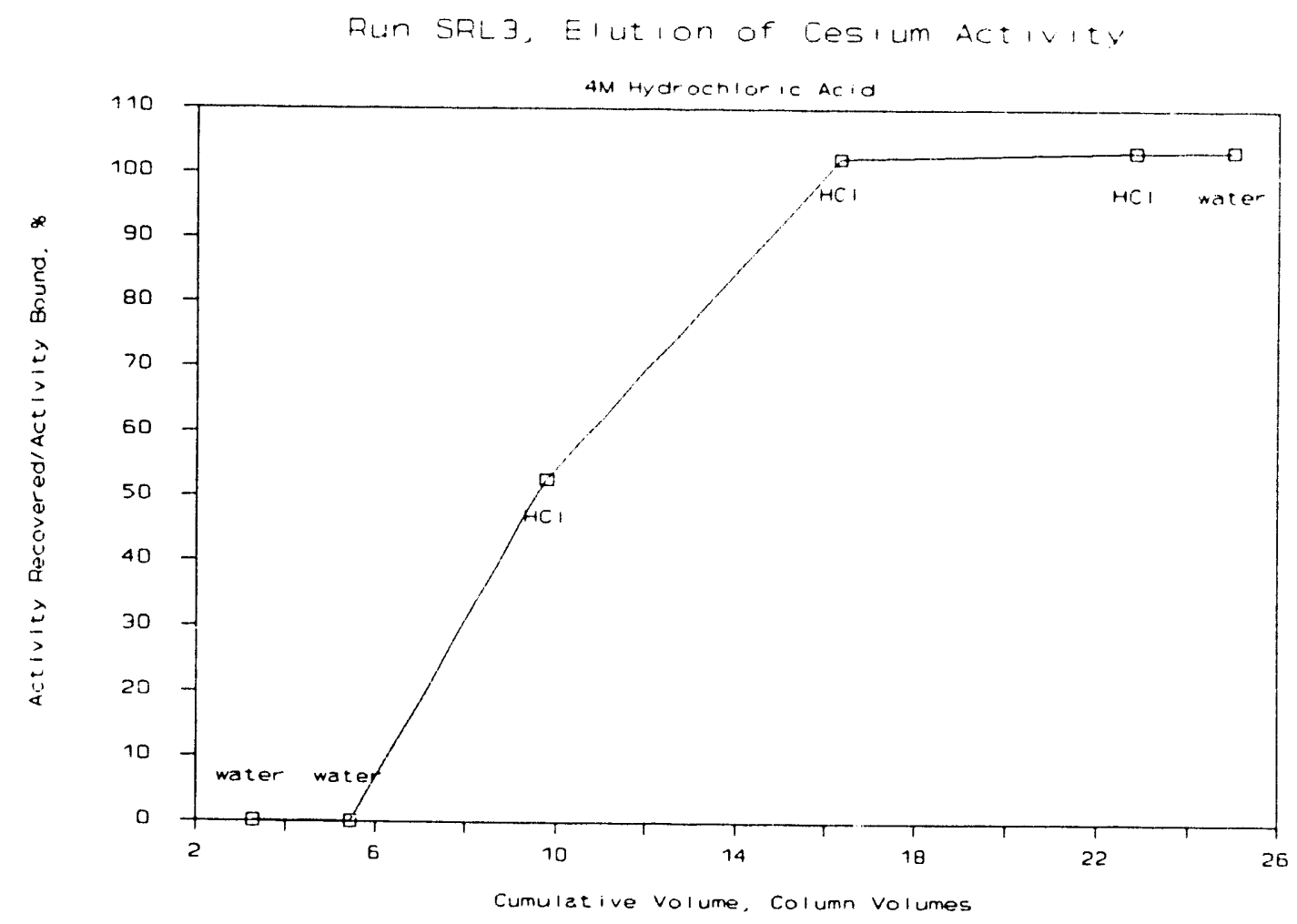

Run SIMSRL5, Resin EIution

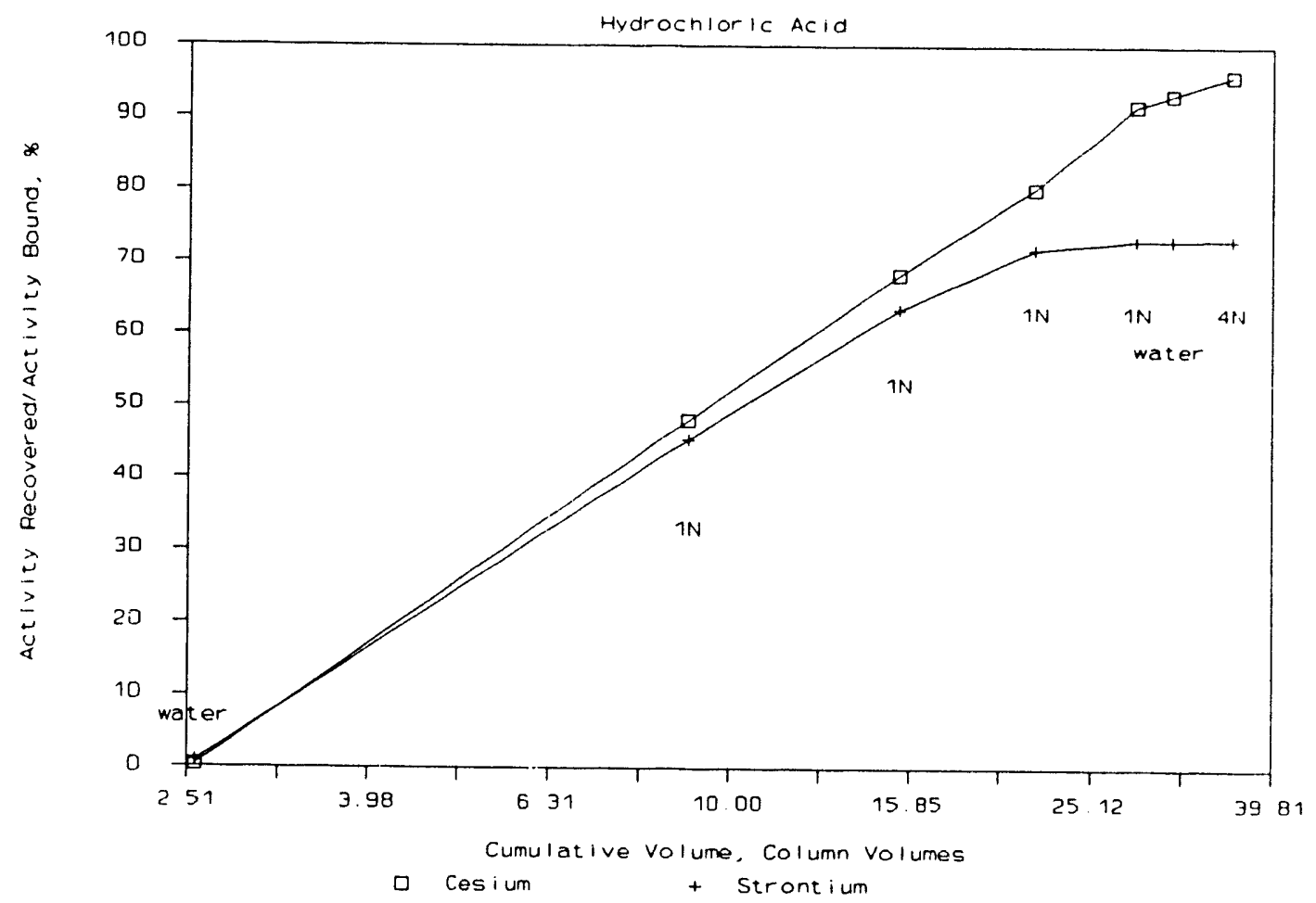

Fig. 4. Elution of activity from SRS resin 
$\Theta_{\mathrm{m}}=$ mean time of the function $\left(\Theta-\Theta_{0}\right.$ at $\left.\mathrm{C} / \mathrm{C}_{0}=0.63\right)$, and

$\beta=$ shape factor for the curve (slope, if curve is straight line).

Analysis consists of plotting the $\log \left\{\ln \left(1 /\left(1-C / C_{0}\right)\right)\right\}$ vs $\log \left(\Theta-\Theta_{0}\right)$. If a straight line emerges, the slope is $\beta$, and $\Theta_{m}$ is the value of $\left(\Theta-\Theta_{0}\right)$ at $\ln \left(1 /\left(1-C / C_{0}\right)\right)=1$, as shown in Fig. 5. Other parameters can be calculated once the breakthrough function is determined, including the mass transfer coefficient $\left(\mathrm{K}_{\mathrm{r}} \mathrm{a}, \mathrm{s}^{-1}\right)$, heigh i of a transfer unit (HTU, cm), the distribution coefficient $\left(K_{d}^{\prime} J\right)$, the time of bed saturation $\left(\Theta_{s}\right)$, and the resin capacity $\left(q_{0}\right)$.

Parameters obtained from the column runs using the method of Doulah and Jafar are shown in Table 9. Values of $K_{d}^{\prime}$ s obtained by both the graphical method $\left(K_{d}^{\prime}\right)$ and calculations using the breakthrough function method $\left(K_{d}^{\prime} J\right)$ are given. The comparison is also shown in Fig. 6 for the cesium $K_{d}^{\prime}$ s and shows that the calculation method gives consistantly larger values. Comparison of $\mathrm{K}_{\mathrm{f}} \mathrm{a}$ to $\mathrm{K}_{\mathrm{l}} \mathrm{a}$, the liquid film mass transfer coefficient based on the system hydrodynamics ${ }^{7}$ shows that the system is limited by the mass transfer inside the resin particle. Indeed, the intraparticle diffusion coefficients that havebeen measured for organic ion-exchange resin systems are generally lower by two orders of magnitude compared with the fluid-phase diffusion. ${ }^{8}$

\section{SUMMARY}

Several inorganic ion exchangers provide extremely large distribution coefficients for

${ }^{137} \mathrm{Cs}$ and ${ }^{90} \mathrm{Sr}$, even in the presence of high concentrations of sodium and moderate amounts of potassium. This unusually high selectivity allows more flexibility in application than do the more familiar processes.

The most valuable characteristic of the ferrocyanides is their extreme selectivity for cesium. With high-salt waste concentrates, which generally present the greatest problem, these reagents are remarkably effective. In many cases, they can be used in a head-end clarification step that is often automatically required, and this may provide an adequate process by itself.

Both the batch and the column results verify that SRS resin has excellent properties for cesium removal but shows much poorer results for strontium. It is effective in high-pH, high-salt solutions, particularly for cesium. Cesium removal is strongly dependent on the potassium concentration, while strontium removal is dependent on the sodium or total alkali metal content. This will allow relatively small ion-exchange columns to be used for ${ }^{137} \mathrm{Cs}$ removal if very little ${ }^{90} \mathrm{Sr}$ is present. In cases of high strontium concentrations, another resin column or a mixture of resins may be required to remove both of the contaminants. 


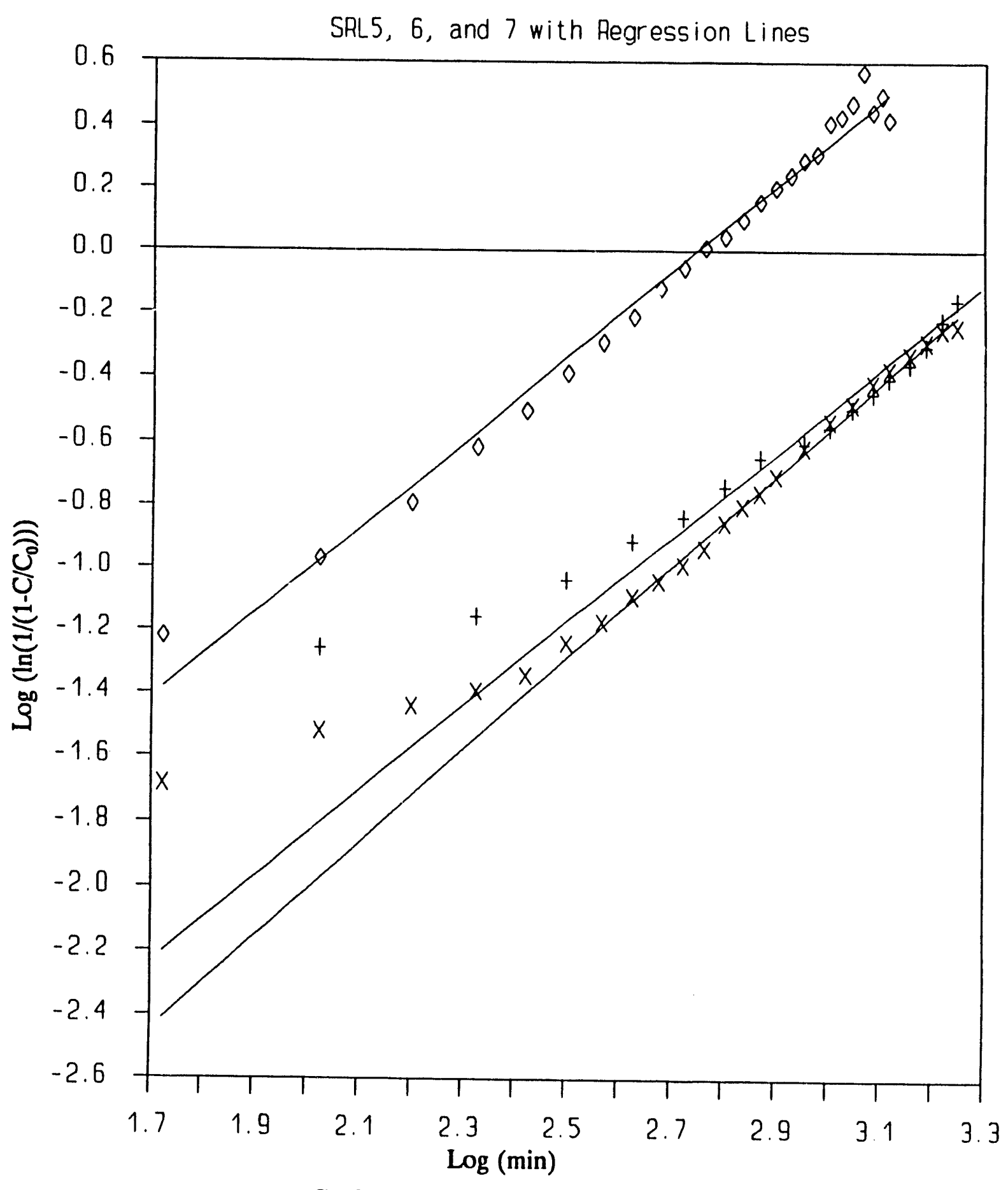

$\diamond \mathrm{Cs}, \mathrm{SRL} 5 \times \mathrm{Cs}, \mathrm{SRL6}+\mathrm{Cs}, \mathrm{SRL} 7$

Fig. 5. SRS resin breakthrough function curves 
Table 9. Data for SRS resin column runs

\begin{tabular}{|c|c|c|c|c|c|c|c|c|c|c|c|}
\hline \multicolumn{12}{|c|}{ A. Cesium } \\
\hline & & SRLI & SRL2 & $\mathrm{NaKl}$ & & SRL3 & SRL4 & SRL5 & SRL6 & SRL7 & $\overline{\mathrm{Nal}}$ \\
\hline$K_{d}^{\prime}$ & - & 755 & 546 & 692 & & 759 & 348 & 219 & 876 & 1587 & 7293 \\
\hline $\mathrm{K}_{\mathrm{d}}^{\prime} \mathrm{J}$ & $=$ & 1000 & 815 & 954 & & 1054 & 421 & 258 & 1045 & 1703 & 8619 \\
\hline $\mathrm{K}_{\mathrm{f}} \mathrm{a}$ & $=$ & $5 E-6$ & $5 E-6$ & $4 E-6$ & & $1 E-6$ & $2.4 E-5$ & $4 E-5$ & $9 E-6$ & $9 E-6$ & $.6 E-9$ \\
\hline${ }^{a} K_{1} a$ & $=$ & 0.0296 & 0.0327 & 0.0325 & & 0.0146 & 0.0795 & 0.0795 & 0.0789 & 0.0789 & 0.0325 \\
\hline Htu & & 4655 & 5437 & 6111 & & 3901 & 1094 & 663 & 2671 & 2849 & 19540 \\
\hline & & 4965 & 3260 & 3615 & & 18642 & 1304 & 799 & 3120 & 6174 & 31827 \\
\hline & & 1.405 & 0.934 & 0.894 & & 1.033 & 1.475 & 1.350 & 1.447 & 1.330 & 1.478 \\
\hline Int & & -5.175 & -3.256 & -3.151 & & 4.219 & -4.427 & -3.706 & -4.903 & -4.494 & -5.424 \\
\hline$\theta_{m}$ & & 4815 & 3067 & 3351 & & 12168 & 1005 & 557 & 2447 & 2398 & 22213 \\
\hline$\Theta_{0}$ & & 150 & 193 & 264 & & 6473 & 298 & 241 & 672 & 3775 & 9614 \\
\hline$q_{0}$ & & $2.3 \mathrm{E} 6$ & $2.1 \mathrm{E} 6$ & $2.4 \mathrm{E} 6$ & & $2.6 \mathrm{E} 6$ & 1. $1 \mathrm{E} 6$ & $6.3 \mathrm{ES}$ & $2.6 \mathrm{E} 6$ & $5.9 \mathrm{E} 6$ & $1.8 \mathrm{E} 7$ \\
\hline $\mathrm{H}$ & & 5.3 & 5.2 & 4.85 & & 4.6 & $3 . y$ & 3.9 & 3.7 & 4.35 & 4.75 \\
\hline $\mathrm{a}$ & & 10.77 & 10.77 & 10.77 & & 10.77 & 19.67 & 19.67 & 19.67 & 19.67 & 10.77 \\
\hline \multicolumn{12}{|c|}{ B. Strontium } \\
\hline & & & & & & & SRL4 & SRL5 & SRL6 & SRL7 & \\
\hline & & & & & $K_{d}^{\prime}$ & $=$ & 94 & 102 & 99 & 433 & \\
\hline & & & & & $\mathrm{K}_{\mathrm{d}}^{\prime} \mathrm{J}$ & $=$ & 145 & 130 & 112 & 436 & \\
\hline & & & & & $K_{f} a$ & $=$ & $2.6 \bar{E}-4$ & 2. $2 E-4$ & $2.0 E-4$ & $7.8 E-5$ & \\
\hline & & & & & $\mathrm{K}_{1} \mathrm{a}$ & $=$ & 0.0795 & 0.0795 & 0.0789 & 0.0789 & \\
\hline & & & & & Htu & $=$ & 103 & 122 & 131 & 337 & \\
\hline & & & & & $\theta_{\mathbf{s}}$ & $=$ & 451 & 403 & 334 & 1581 & \\
\hline & & & & & & $=$ & 4.04 & 2.82 & 2.34 & 2.07 & \\
\hline & & & & & Int & $=$ & -9.75 & -6.57 & -5.35 & -5.47 & \\
\hline & & & & & $\theta_{\mathrm{m}}$ & $=$ & 260 & 214 & 194 & 441 & \\
\hline & & & & & $\theta_{0}$ & $=$ & 190 & 188 & 140 & 1140 & \\
\hline & & & & & $q_{0}$ & $=$ & $3.0 \mathrm{E} 5$ & $3.2 \mathrm{E} 5$ & $2.7 \mathrm{E} 5$ & $1.5 \mathrm{E} 6$ & \\
\hline
\end{tabular}

${ }^{a}$ Carberry's Correlation $=K_{1}=1.15\left(p_{1} D_{p} U_{s} / \mu_{1} / \epsilon\right)^{-1 / 2}\left(\mu_{1} / \rho_{1} / D\right)^{-2 / 3}\left(U_{s} / \epsilon\right)$

Col diameter, $d=1.12838 \mathrm{~cm}$

Resin bulk dry density $=0.848$

$\epsilon=$ Void fraction $=0.4$

$\mu_{1}=$ viscosity $-0.01 \mathrm{~g} / \mathrm{cm} \cdot \mathrm{s}$

$D=$ Diffusion coefficient $\sim 2 \times 10^{-5} \mathrm{~cm}^{2} / \mathrm{s}$

$H=$ bed height $(\mathrm{cm})$

$a=\epsilon^{2 * 1.5 / D_{p}\left(\mathrm{~cm}^{-1}\right)}$

$p_{1}=$ liquid density $-1.24 \mathrm{~g} / \mathrm{cm}^{3}$ 


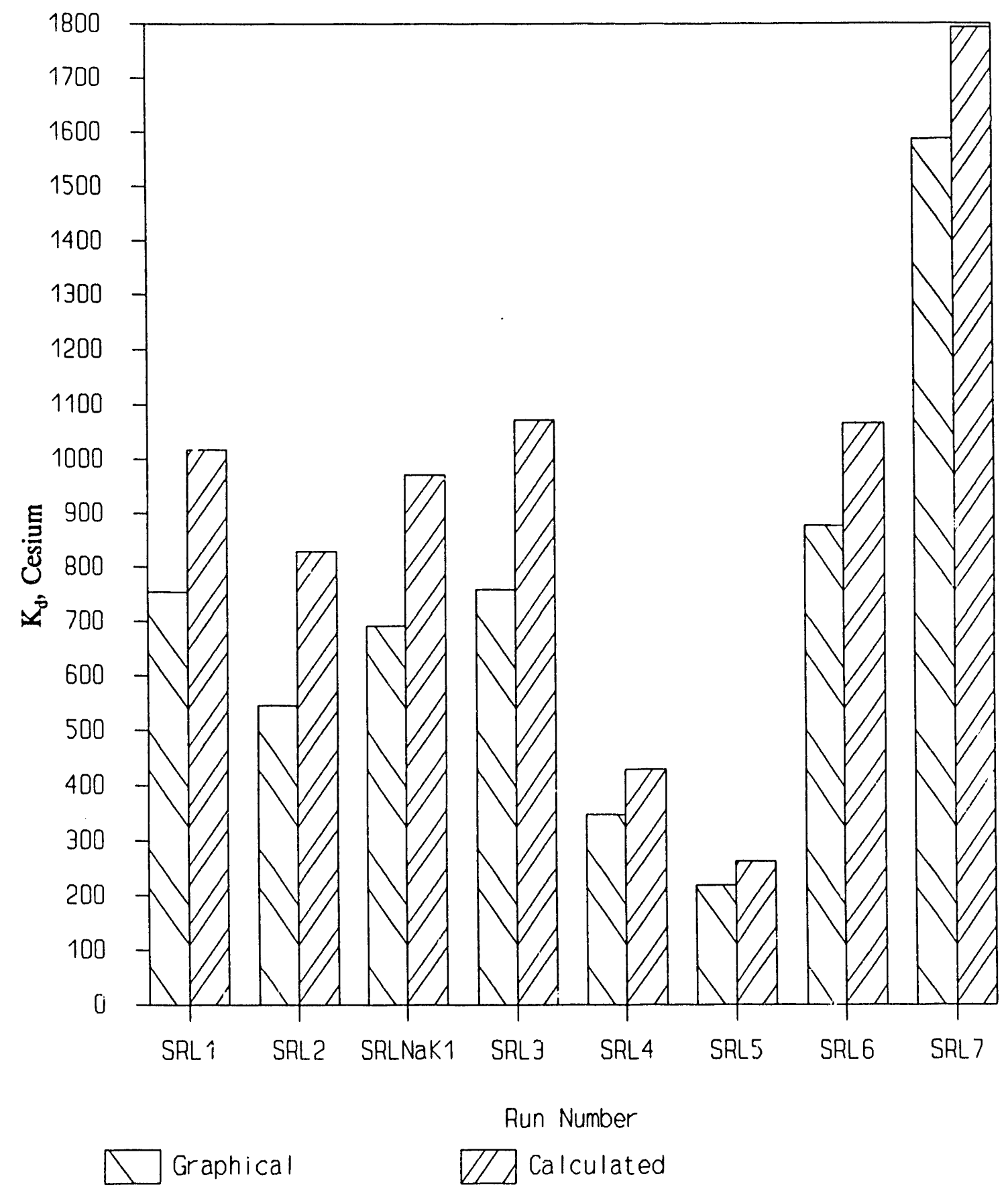

Fig. 6. Cesium Kds for column tests by graphical and breakthrough function methods 


\section{REFERENCES}

1. D. O. Campbell, E. D. Collins, L. J. King, and J. B. Knauer, "Evaluation of the Submerged Demineralizer System (SDS) Flowsheet for Decontamination of HighActivity-Level Water at the Three Mile Island Unit 2 Nuclear Power Station," ORNL/TM-7448, Oak Ridge National Laboratory (July 1980).

2. V. Kourim, J. Rais, and B. Million, "Exchange Properties of Complex Cyanides - I; Ion Exchange of Cesium Ferrocyanides," J. Inorg. Nucl. Chem., 26, 1111 (1964).

3. W. E. Prout, E. R. Russell, and H. J. Groh, "Ion-Exchange Absorption of Cesium by Potassium Hexacyanocobalt(II)ferrate(II)," J. Inorg. Nucl. Chem., 27, 473 (1965).

4. J. P. Bibler, R. M. Wallace, and L. A. Bray, "Testing a New Cesium-Specific Ion-exchange Resin for Decontamination of Alkaline-High Activity Waste," presented at Waste Management '90, Tucson, Arizona, February 25 - March 1, 1990.

5. E. D. Collins, D. O. Campbell, L. J. King, J. B. Knauer, and R. M. Wallace, Evaluation of zeolite mixtures for decontaminating high-activity-level water at the Three Mile Island Unit 2 Nuclear Power Station, p.43 in "Inorganic Ion Exchangers and Adsorbents for Chemical Processing in the Nuclear Fuel Cycle," IAEATECDOC-337 (1984).

6. M. S. Doulah and S. A. Jafar, "A method for the prediction of mass transfer parameters in an ion exchange process," pp. 293-305 in Ion Exchange for Inctustry, Michacl Streat, ed., Ellis Horwood, Limited, Chichester, England (1988).

7. J. J. Carberry, "A Boundary Layer Model of Fluid-Particle Mass Transfer in Fixed Beds," AIChEJ, 6(3), 460 (1960).

8. Chemical Engineers' Handbook, Fifth ed., 16-19 (J. H. Perry et al., eds.) McGrawHill, New York (1973). 
ORNL/TM-11891

\section{INTERNAL DISTRIBUTION}

1. H. L. Adair

2. J. M. Begovich

3. J. T. Bell

4. J. B. Berry

5. W. D. Bond

6. C. H. Brown, Jr.

7. C. O. Campbell

8. R. M. Canon

9. E. D. Collins

10. K. W. Cook

11. A. G. Croff

12. T. A. Dillow

13. S. M. DePaoli

14. C. P. East

15. B. Z. Egan

16. W. Fulkerson

17. R. K. Genung

18. J. R. Hightower

19. V. T. Hinkel

20. L. Holder

21. E. K. Johnson

22. C. M. Kendrick

23. T. E. Kent
24. J. R. Lawson

25-26. D. D. Lee

27. J. J. Maddox

28. R. C. Mason

29. A. J. Mattus

30. L. E. McNeese

31. L. J. Mezga

32. J. J. Perona

33. D. J. Peterson

34. S. M. Robinson

35. T. F. Scanlan

36. C. B. Scott

37. M. G. Stewart

38. P. A. Taylor

39. J. R. Trabalka

40. D. W. Turner

41. E. L. Youngblood

42. Cen. Res. Library

43. Doc. Ref. Section

44. Lab Records

45. Lab Records. R.C.

46. ORNL Pat. Sect.

\section{EXTERNAL DISTRIBUTION}

47. Office of Assistant Manager, Energy Research and Development, DOE-OR, P. O. Box 2001, Oak Ridge, TN 37831-8600

48-57. Office of Scientific and Technical Information, P. O. Box 62, Oak Ridge, TN 37831 


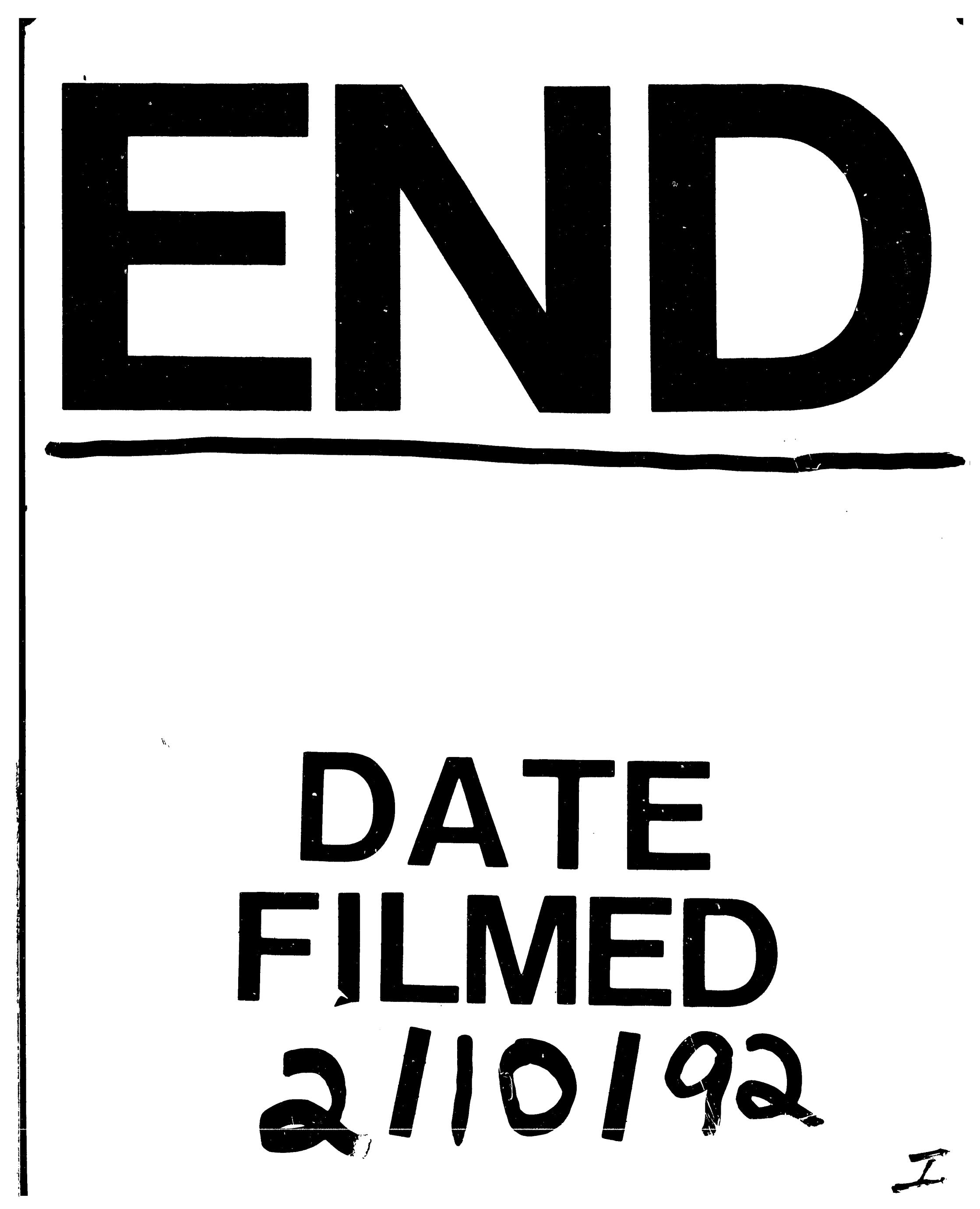


